\title{
Morphology of the Middle Ear in Three Species of Armadillos (Dasypodidae, Xenarthra) from Argentina
}

\author{
Morfología del Oído Medio en Tres Especies de Armadillos (Dasypodidae, Xenarthra) de Argentina
}

\author{
"Nora S. Sidorkewicj \& *,** Emma B. Casanave
}

\begin{abstract}
SIDORKEWICJ, N. S. \& CASANAVE, E. B. Morphology of the middle ear in three species of armadillos (Dasypodidae, Xenarthra) from Argentina. Int. J. Morphol., 30(4):1500-1507, 2012.

SUMMARY: Middle ears of adult Chaetophractus villosus, C. vellerosus and Zaedyus pichiy were studied for qualitative and quantitative comparisons. A great similarity in the overall shape of the middle ear structures was observed in the three species. The well-developed auditory bulla was formed by the intimate fusion of the tympanic and entotympanic. Internally, a recessus meatus and a wide epitympanic recess extending dorsally into an epitympanic sinus were recognized. The petrosal promontorium, nearly triangular, was the most salient feature in the tympanic cavity. The auditory ossicles corresponded to the transitional middle ear type. The $\mathrm{m}$. tensor tympani and the $\mathrm{m}$. stapedius were conspicuous. The lack of a stapedial artery was confirmed in all cases. The tympanic area and middle ear ossicles were relatively larger in C. vellerosus than in the other two species. It is hoped that the results of the present paper coupled to the bullar hypertrophy found in a previous work will provide a significant basis for future functional studies on the hearing capabilities in the dasypodids.
\end{abstract}

KEY WORDS: Chaetophractus villosus; Chaetophractus vellerosus; Zaedyus pichiy; Fossorial; Middle ear.

\section{INTRODUCTION}

Dasypodidae (Xenarthra: Cingulata) is a family of fossorial mammals, commonly known as armadillos. Twenty-one extant species are known, gathered into five groups (Euphractini, Dasypodini, Priodontini, Tolypeutini, Chlamyphorini), that are mainly distributed in South America (Gardner, 2005). They represent the most diverse assemblage within the xenarthrans, and have been the subject of several studies in an attempt to elucidate the still unresolved phylogeny of Cingulata (Gaudin et al., 1996; Delsuc et al., 2003; Gaudin \& Wible, 2006).

Anatomical and physiological adaptations towards a fossorial lifestyle could be extreme (Nevo, 1979) and may involve several kind of strategies to increase low-frequency hearing. In general, transmission of low-frequency sounds by the middle ear will be increased by hypertrophied middle ear cavities, enlarged tympanic membranes and ossicles with loose ligamentar attachments (Khanna \& Tonndorf, 1969;
Plassman \& Brändle, 1992; Schleich \& Vasallo, 2003). Although many studies are available on the hearing adaptations in large and small burrowing mammals (Nevo; Burda et al., 1992; Mason, 2001; Schleich \& Vassallo; Lange et al., 2004), the reports on dasypodids are less abundant. Some of the contributions on the morphology of the ear region in these animals come from Segall (1976), Patterson et al. (1989, 1992), Gaudin et al., Wible \& Gaudin (2004), Squarcia et al. (2007) and Wible (2010).

The purpose of the present study was threefold: i) to perform a morphological description of the middle ear region -with special emphasis in the auditory ossicles- in three dasypodids of the Euphractine group, Chaetophractus villosus, C. vellerosus and Zaedyus pichiy; ii) to carry out a morphometric comparative study of the eardrum and middle ear bones in the three species; and iii) to evaluate the relationship of these structures with the tympanic bulla and skull.

\footnotetext{
* Departamento de Biología, Bioquímica y Farmacia, Universidad Nacional del Sur, San Juan 670, 8000 Bahía Blanca, Argentina.

*** Member of the Researcher Career of the Consejo Nacional de Investigaciones Científicas y Técnicas, CONICET, Argentina.

Funded by the Secretaría General de Ciencia y Tecnología, Universidad Nacional del Sur, Project 24/B152.
} 


\section{MATERIAL AND METHOD}

Adult skulls of Chaetophractus villosus ( $\mathrm{n}=14), C$. vellerosus $(\mathrm{n}=13)$ and Zaedyus pichiy $(\mathrm{n}=14)$ were taken from the collection of the Laboratory of Comparative Anatomy (Department of Biology, National University of South, Argentina), and come from the South of Buenos Aires Province, Argentina.

The middle ear structures were observed under a stereoscopic microscope. The ossicles were extracted and morphometric measurements were performed using a micrometric lens: a) for the malleus: total length (TLM), head diameter (HDM) and manubrium length (MLM); b) for the incus: total width (TWI) and total length (TLI); c) for the stapes: total length (TLS) and base width (BWS) (Fig. 1). The cross-diameters of the eardrum were measured by means of a digital calliper $(0.01 \mathrm{~mm})$ and the area $(\mathrm{TA})$ was then calculated.

Mean values of the measured traits were compared among species by means of one-way ANOVA and Least Significant Difference (LSD; $\mathrm{p} \leq 0.05$ ). Linear regression analyses were performed of middle ear parameters against body mass, over log-transformed data. Regression analyses were also carried out of the measured traits versus the total length of the skull (STL, anterior edge of the premaxilla to the posteriormost point of the nuchal crest). The percent relationship between the measured parameters and STL was calculated in each species, and differences between mean values were tested by LSD $(p \leq 0.05)$.

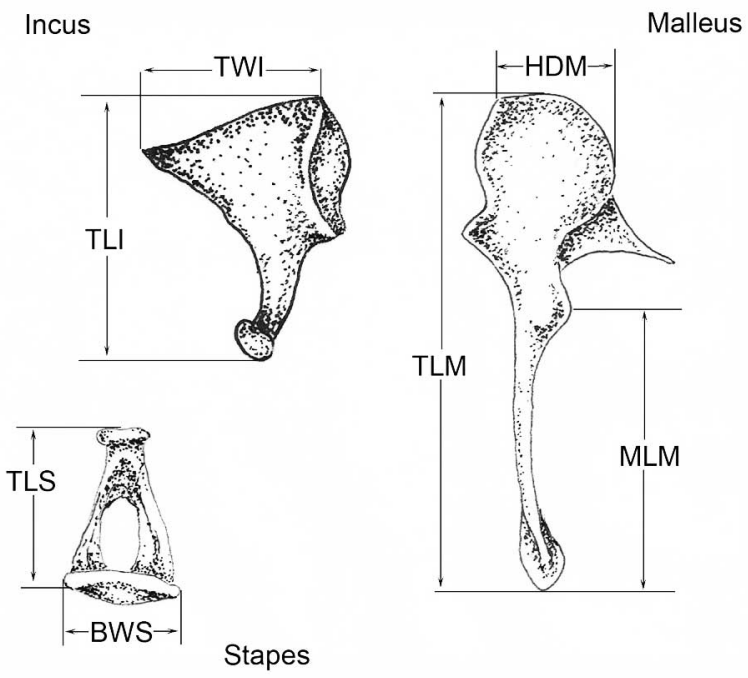

Fig. 1. Generalized dasypodid's left auditory ossicles to illustrate the measured traits. For abbreviations see text.

\section{RESULTS}

Morphology of the middle ear structures. The bulla was completely ossified and hypertrofied in the three species (see Squarcia et al.). It was dome-shaped and elongated, with its major diameter oblique with respect to the sagital plane of the skull. It had a triangular silhouette in ventral view, its caudal end being wider and more rounded than the rostral one. The bulla was formed by the tympanic (=ectotympanic) and entotympanic which were well fused, making it difficult to see the limits between them. The tympanic contributed also to the final part of the external acoustic meatus, which entered the bulla; so in ventral view the medial two-thirds of the bulla corresponded to the floor of the tympanic cavity and the lateral one-third to the recessus meatus.

Internally, adjacent to the recessus meatus was the epitympanic recess (Fig. 2A, B, C), deeply extending dorsally into the epitympanic sinus. Ventromedially to this recess was the tympanic cavity proper, in which anteriomedial wall was the opening of the auditive tube. The promontorium of the petrosal was elongated and big, and made a nearly triangular protrusion pointing latero-caudally; it was composed of thick, opaque bone. The fenestra vestibuli (oval window), located at the posterolateral wall of the promontorium, and the fenestra cochleae (round window), placed at its posterior surface and ventral to the f. vestibuli, were separated by the crista interfrenestralis. Projecting anteromedially from the promontorium was a large epitympanic wing.

The sulcus tympanicus and crista tympanica (Fig. 2B, C), that marked the position of the tympanus, were conspicuous. The pars tensa was slightly oval, the rostrocaudal diameter being longer than the dorsoventral one. The pars flaccida was small and triangular.

The overall shape of the middle ear ossicles was rather similar in the three species, with subtle differences. The head of the malleus (Fig. 2E, F, G) was located in the epitympanic recess; its posterior side was almost triangular in C. villosus, and more flattened in the other two species, especially in $Z$. pichiy. The articular surface for the incus was saddle-shaped and surrounded by a low labrum. It consisted of two facets forming between them an obtuse angle; the vertical facet was larger than the horizontal one only in both Chaetophractus species. At the junction of the malleolar head with the neck emerged a long anterior process (=processus gracilis), directed anteroventrally to fuse with the ectotympanic via a thin goniale; the degree of fusion was such that the $\mathrm{p}$. gracilis was broken in all specimens when removing the malleus, its distal half being attached to the ectotympanic. The neck was short and laterally compressed, 

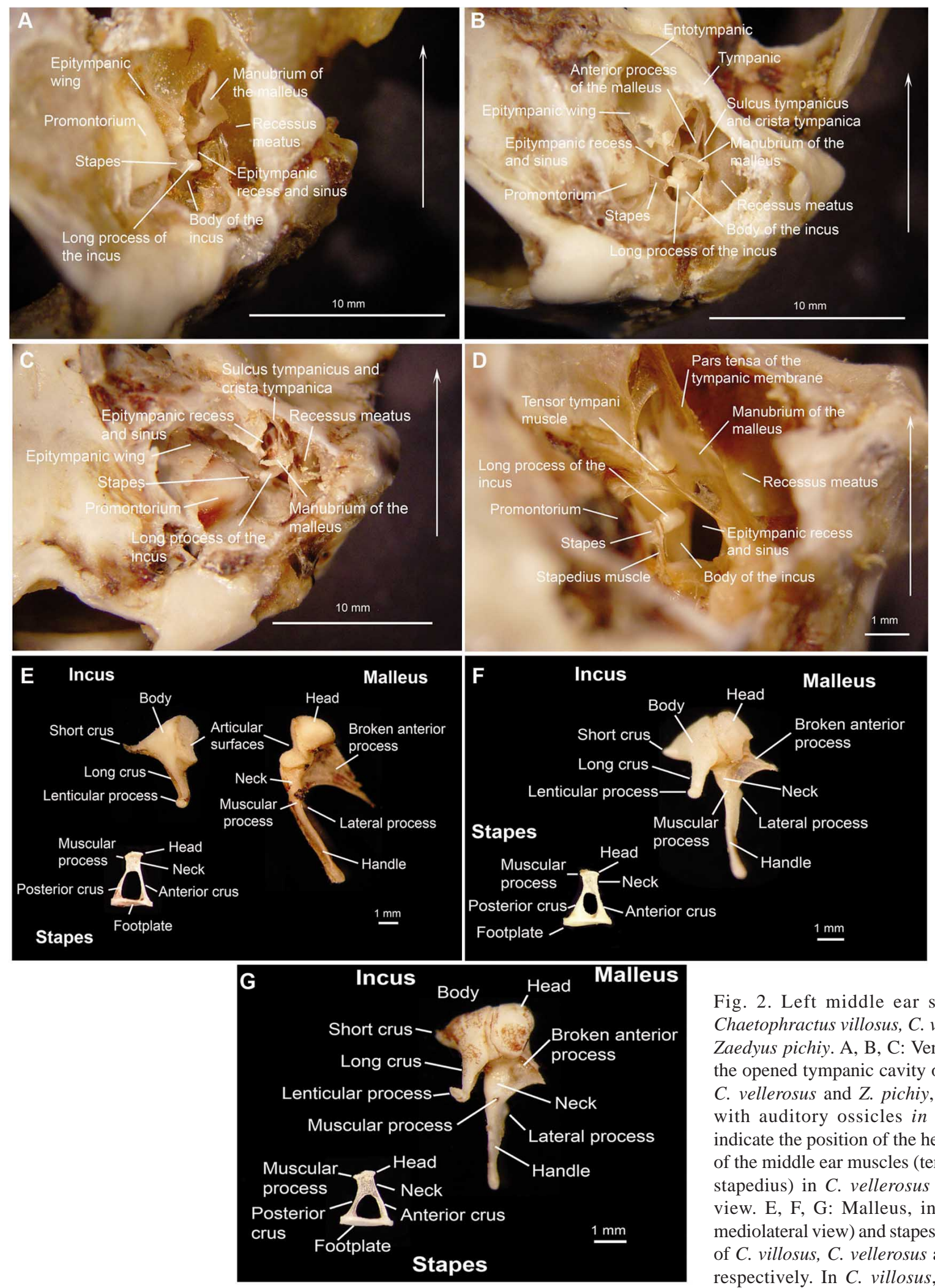

Fig. 2. Left middle ear structures of Chaetophractus villosus, C. vellerosus and Zaedyus pichiy. A, B, C: Ventral views of the opened tympanic cavity of C. villosus, C. vellerosus and Z. pichiy, respectively, with auditory ossicles in situ (arrows indicate the position of the head). D: detail of the middle ear muscles (tensor tympani, stapedius) in C. vellerosus from ventral view. E, F, G: Malleus, incus (both in mediolateral view) and stapes (dorsal view) of C. villosus, C. vellerosus and Z. pichiy, respectively. In $C$. villosus, none of the malleus-incus units could be recovered as such, so disarticulated bones were photographed. 
and bore a small muscular process for the fastening of a prominent tensor tympani muscle (Fig. 2D). The handle or manubrium was attached to the medial surface of the pars tensa, determining a dorsoventral malleolar stria. At the base of the handle the lateral process formed the malleolar prominence over the dorsal end of the malleolar stria. The manubrium decreased in size and became slightly curved towards its end, expanding distally to form a spatulate tip that supported the umbo of the eardrum.

The incus was nearly equal in the three species (Fig. $2 \mathrm{E}, \mathrm{F}, \mathrm{G})$. The body, totally suspended in the epitympanic recess, was roughly rectangular, elongated and slightly compressed laterally. The articular surface for the malleus presented a wide, S-shaped articular facet, bordered by a low labrum. The short process was conical and pointed caudodorsally, with a light inclination towards the external side of the ear. The long process was cylindrical and extended ventrally almost parallel to the handle of the malleus; it turned in its final third towards the inner ear, to articulate with the stapes. The tip of the long crus supported a small an oval lenticular process.

The stapes of the three species (Fig. 2E, F, G) had a normal stirrup-like appearance, with its long axis oriented horizontally. The small head or capitulum was flat and oval, and articulated with the lenticular process of the incus through a small facet. The capitulum tapered to give rise to a delicate and relatively long neck; at that point there was a faint muscular process for the insertion of a conspicuous stapedius muscle, which attached the stapes to the tympanic pyramid of the caudal wall of the bulla (Fig. 2D). The anterior and posterior crura as well as the intercrural foramen were different in the three species. In C. villosus, the anterior crus was straight, the posterior crus convex, and the intercrural foramen rectangular and big. In Z. pichiy the stapes was very thin and delicate; the anterior/posterior crura were convex/straight, and the foramen triangular and smaller than in $C$. villosus. The stapes of $C$. vellerosus had straight crura and the smallest foramen, which was ovoid. In all cases, the crura were internally hollowed by sulci, as was the neck. The footplate or base was oval, and the insertion of the crura over it was asymmetrical. The labrum was well developed, and the center of the footplate was slightly convex towards the vestibule of the inner ear. The lack of a stapedial artery was confirmed in all specimens.

The incudomalleolar and incudostapedial joints were of synovial type, the former being stiffer in $C$. vellerosus than in C. villosus and Z. pichiy.

Morphometry. Significant differences existed between the species under study in almost all the morphological traits considered (Fig. 3). The mean absolute values were significantly highest in C. villosus, intermediate in $C$. vellerosus and lowest in Z. pichiy, except for TA and BWS that did not differ between $C$. villosus and $C$. vellerosus notwithstanding their different cranial size (mean STL \pm standard deviation: $91.1 \pm 2.7$ for $C$. villosus; $66.1 \pm 1.8$ for $C$. vellerosus; $66.8 \pm 1.6$ for $Z$. pichiy).

For each species, the regression analyses between the size of the middle ear parameters and the body mass were not significant in the majority of cases ( $p>0.09)$, except for TLM in C. villosus ( $\mathrm{p}=0.007, \mathrm{r}=0.68$ ) and HDM in $Z$. pichiy $(\mathrm{p}=0.02, \mathrm{r}=0.62)$. The same tendency was observed when middle ear parameters were correlated with STL, excepting TLM ( $\mathrm{p}=0.03, \mathrm{r}=0.60)$ and TWI $(\mathrm{p}=0.002, \mathrm{r}=0.75)$ in $C$. villosus, and TA ( $\mathrm{p}=0.03, \mathrm{r}=0.60)$ and TLI $(\mathrm{p}=0.02, \mathrm{r}=0.60)$ in $C$. vellerosus. However the specific mean percent relationship (MPR) between STL and all the measured parameters showed that $C$. vellerosus had the relatively longest eardrum and ossicles when compared with the other two species (Fig. 3).

\section{DISCUSSION}

Our results showed that, despite the existence of clear differences in the relative size of the middle ear structures of $C$. villosus, $C$. vellerosus and $Z$. pichiy, the interspecific variability in their overall shape is negligible. As reported by Squarcia et al., the three species have well-developed bullae, formed by the early fusion of the tympanic and entotympanic. According to previous studies (Patterson et al., 1989; Wible, 2010), the dasypodids most different from Euphractines in terms of the morphology of the middle ear are the Dasypodines, another group commonly represented near the study area (Dasypus hybridus; Casanave et al., 2003); the possession of a ring-shaped tympanic, a poorly ossified entotympanic, a narrow recessus meatus, a small epitympanic recess and the lack of an epitympanic sinus, could be mentioned as some of their most salient features.

The middle ear apparatus of mammals have been the subject of many studies concerning differences in auditory sensitivity (Fleischer, 1978; Hemilä et al., 1995; Nummela, 1995; Mason; Lavender et al., 2011). Based on Fleischer, most terrestrial mammals can be categorized into two basic middle-ear types based on their ossicular morphologies, with a range of intermediate or transitional morphology falling between both extremes. The first type, called the "microtype", is characterized by having a malleus with a long process (processus gracilis) fused to the ectotympanic via a goniale, a wide transversal lamina between the 


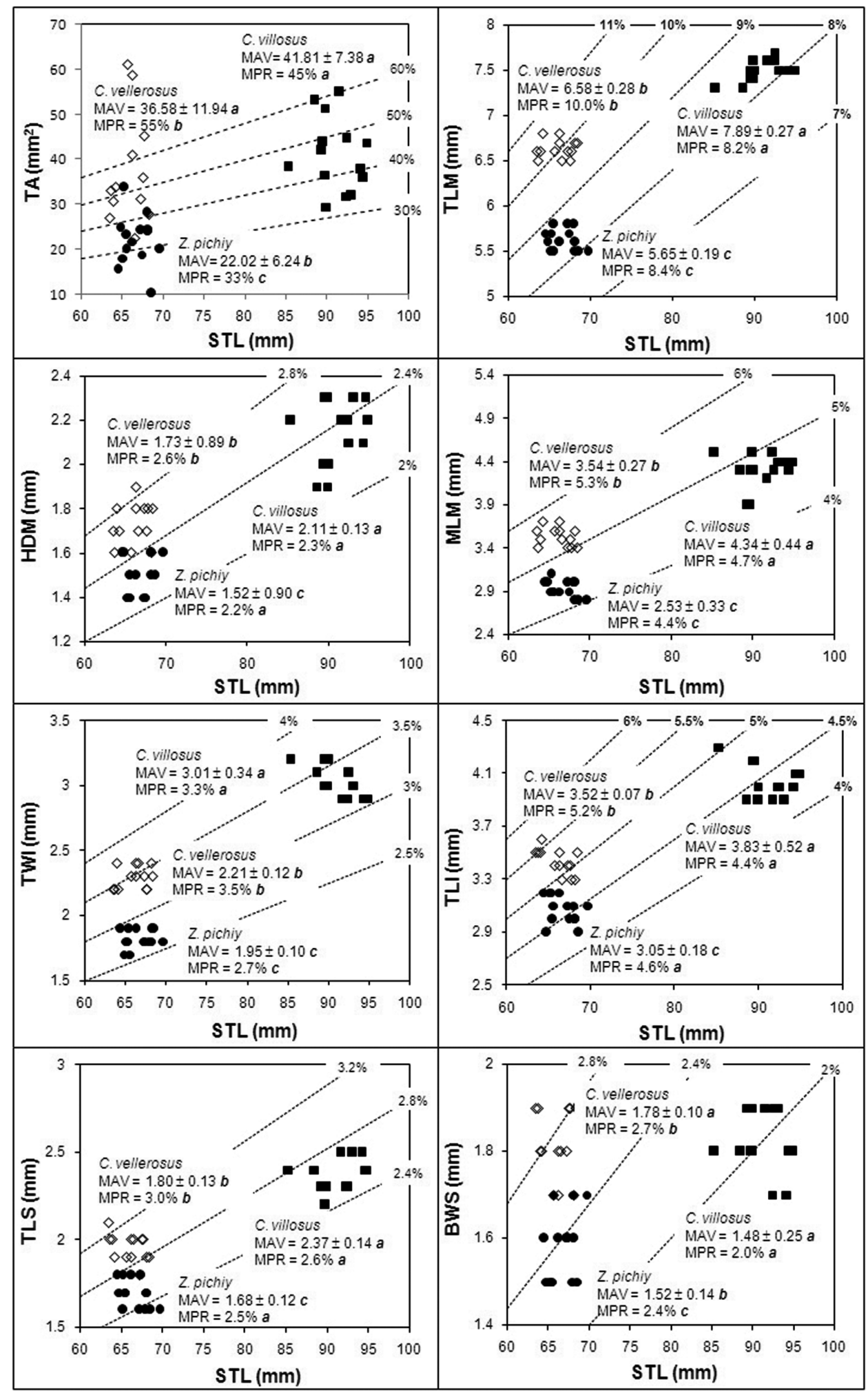

Fig. 3. Scatter plot of the measured traits for middle ear structures versus the skull length in Chaetophractus villosus, C. vellerosus and Zaedyus pichiy. Significant differences between species in the mean absolute values (MAV) and in the mean percent relationship (MPR) are indicated by different letters (s.d.: standard deviation). The dashed lines correspond to the isolines for the PR. Abbreviations in text. 
manubrium and the articular surface (for the incus), and a prominent bony mass near the base of the manubrium called the orbicular apophysis. The incus is small relative to the malleus. The microtype is thought to be similar to the hypothesized mammalian ancestral type and is characteristic of small mammals with a good high-frequency hearing such as bats, shrews, and many rodents. By contrast, at the other end of the stiffness spectrum is the "freely mobile" type where the ossicular connection to the skull is loose; the malleus has a well developed head but lacks a transversal lamina and also orbicular apophysis, and the long process has shortened into a truncated process (the anterior process), not fused to the tympanic but attached to it via the anterior ligament. The incus is enlarged relative to the malleus. The malleus head and manubrium lie in the same line with each other and with the long process of the incus. The malleusincus unit has moved dorsally compared with the other middle ear type. Together, these adaptations bring compliance to the ossicular chain, being well suited for transmitting low frequencies, and are commonly found in large terrestrial species such as primates, elephants, and some carnivores. The ossicular morphology observed in our species corresponded to a transitional middle ear type (sensu Fleischer), since the processus gracilis is attached to the tympanic, the incus has increased in size relative to the malleus, and the malleus-incus unit has rotated dorsally compared to the microtype; as Fleischer suggested, this morphology could be primitive with respect to the freely mobile, and seems to be suitable for transmitting somewhat lower frequencies than the microtype.

According to Patterson et al. (1992), the morphology of the malleus allows to divide armadillos in two groups, one of them typified by the malleus of Dasypus ("dasypodidtype"), and the other by the malleus of Chaetophractus ("euphractine-type"). The cited authors reported for Dasypus a malleus with a dorsoventrally elongated head connected by a broad lamina to a large anterior process; the articular facets for the incus set at an acute angle to one another; an indistinct lateral process; and a near 110 degree-angle between the neck and the handle in lateral view. They suggested this dasypodid-type could be primitive for armadillos as a whole, which seems to be in accordance with the fact that Dasypus (D. novemcinctus, D. kappleri) is considered to be the most basal of the living armadillos (Wible, 2010; and references therein). On the contrary, Patterson et al. (1992) reported for the euphractine group (Chaetophractus, Zaedyus) a mallear morphology substantially different than that of Dasypus: a head globose and larger relative to the size of the whole bone itself; the articular facets for the incus set at an obtuse angle to one another; a distinguishable lateral process; an anterior process quite small, with a reduction in the lamina; the neck and the manubrium laid out in the same line in lateral view. Such a description was consistent with the characteristics we observed for the mallei of C. villosus, C. vellerosus and $Z$. pichiy except in the size of the anterior process; the reason for this discrepancy could be that the cited authors based their work in old illustrations of the isolated bones, consequently the anterior process could be broken.

The stapes of living xenarthrans is characterized by morphological variability, not only in its overall shape but also in the lack/existence of a stapedial foramen which results in a wide range from imperforated to widely perforated forms. Our observations agreed with Gaudin et al., who reported that the stapes of most extant armadillos is triangular, with the crura varying from straight-sided (Dasypus), concave-sided (Tolypeutes, Priodontes), slightly convex (Euphractus), or one side straight/the other convex. The existence of a large stapedial foramen seems to be the condition commonly found in armadillos (Patterson et al., 1992; Gaudin et al.); the only known exception up to date is a microperforated stapes reported by Patterson et al. (1992) for Tolypeutes, although previous works indicated for this genus the existence of a large foramen (Doran, 1878; Guth, 1961). Notwithstanding, despite the existence or not of a large stapedial foramen, the lack of the stapedial artery is the feature shared by adult xenarthrans (Wible \& Gaudin). Further studies are needed to elucidate if this vessel, already identified in fetal stages of $D$. novemcinctus (Wible, 1984), is present during the ontogenetic development of Chaetophractus and Zaedyus.

A high degree of development was observed for the tensor tympani and stapedius muscles, both of them attached over distinct muscular processes. Wible \& Gaudin reported a lack of processes for muscular fixation in Euphractus sexcinctus, but they did not mention the degree of muscular development. The existence of well developed middle ear muscles in our species might seem striking if taking into account their burrowing habits, since a reduction or even missing of at least one of these muscles was observed in several fossorial species (Burda et al.; Mason). The exact reason for muscle reduction is still unclear but may represent the strongest evidence for degeneration in the middle ear apparatus of fossorial mammals (Mason). The absence of muscle reduction in dasypodids may be because, although they construct burrows, do not spend a substantial part of their lives underground and therefore would not be "fossorial" in the strict sense.

The ability to effectively pick up low frequency sounds is of vital importance for subterranean mammals because low frequencies are better propagated than higher ones in underground tunnels (Heth et al., 1986). This ability 
is also highly valuable adaptations that develop some species inhabiting arid environments, to detect the low-frequency sounds caused by movements of the approaching predators (Webster \& Webster, 1984; Webster \& Plassmann, 1992). Low-frequency airborne hearing can be improved by relatively large middle ear ossicles with loose ligamentar attachments, large tympanic membranes and an increased bullar volume (Khanna \& Tonndorf; Plassman \& Brändle; Schleich \& Vasallo). In the present study, although the malleus was observed to be fused to the tympanic in the three species, clear interspecific differences in the relative size of the middle ear structures were observed (almost all parameters relatively highest in C. vellerosus, intermediate in $C$. villosus, lowest in Z. pichiy), which sums to previous findings reported by Squarcia et al., concerning the tympanic bulla (mean bullar hypertrophy index: $15.98 \%$ for $C$. vellerosus; $13.96 \%$ for $C$. villosus; $13.52 \%$ for $Z$. pichiy). In view of these results, the most adapted dasypodid to a fossorial lifestyle and/or to eremic conditions seems to be $C$. vellerosus, followed by $C$. villosus and, in the last place, Z. pichiy.

This paper presents anatomical information about the middle ear in armadillos of the Euphractine group. Further studies are required on the functional morphology of the middle ear structures in these animals, in order to gain knowledge about their effectiveness in sound transmission and the limits of the hearing frequency range.

\section{ACKNOWLEDGEMENTS}

The authors thank Dr. S. Squarcia for her critical review of the manuscript. Technical assistance in data collection by Lic. G. Cirone, and statistical advice by Prof. R. Camina are also acknowledged.

SIDORKEWICJ, N. S. \& CASANAVE, E. B. Morfología del oído medio en tres especies de armadillos (Dasypodidae, Xenarthra) de Argentina. Int. J. Morphol., 30(4):1500-1507, 2012.

Resumen: Se estudió cualitativa y cuantitativamente la morfología del oído medio en adultos de Chaetophractus villosus, C. vellerosus y Zaedyus pichiy. Se observó una gran similitud en las estructuras del oído medio de las tres especies. La bula auditiva, bien desarrollada, se observó formada por la fusión del timpánico y entotimpánico. Internamente se pudo reconocer un recessus meatus y un amplio receso epitimpánico que se extendía dorsalmente en un seno epitimpánico. El promontorio, casi triangular, fue la estructura más notoria del interior de la cavidad timpánica. Los huesecillos auditivos correspondieron al tipo transicional. Se observó un gran desarrollo en los músculos tensor del tímpano y estapedial. Se confirmó la falta de una arteria estapedial en las tres especies. El área del tímpano y los huesecillos auditivos fueron relativamente más grandes en C. vellerosus que en las otras dos especies. Se espera que los resultados del presente trabajo, sumados a la hipertrofia de la bula timpánica reportada previamente, provean una base significativa para futuros estudios sobre la capacidad auditiva en los dasipódidos.

PALABRAS CLAVE: Chaetophractus villosus; Chaetophractus vellerosus; Zaedyus pichiy; Fosorial; Oído medio.

\section{REFERENCES}

Burda, H. B.; Bruns, V. \& Hickman, G. C. The ear in subterranean Insectivora and Rodentia in comparison with ground-dwelling representatives. I. Sound conducting system of the middle ear. J. Morphol., 214(1):49-61, 1992.

Casanave, E. B.; Manfredi, C. \& Luengos Vidal, E. Ecología comportamental de los armadillos en un pastizal serrano. Actas II Jornadas Interdisciplinarias del Sudoeste Bonaerense, Tomo III, EdiUNS, 2003. pp.115-25.

Delsuc, F.; Stanhope, M. J. \& Douzery, E. J. P. Molecular systematics of armadillos (Xenarthra, Dasypodidae): Contribution of Maximum Likelihood and Bayesian analyses of mitochondrial and nuclear genes. Mol. Phylogenet. Evol., 28(2):261-75, 2003.

Doran, A. H. G. Morphology of the Mammalian Ossicula auditûs. Trans. Linn. Soc. London $2^{\text {nd }}$ Ser. Zool., 1(7):371-497, 1878.
Fleischer, G. Evolutionary principles of the mammalian middle ear. Adv. Anat. Embryol. Cell Biol., 55(5):3-70, 1978.

Gardner, A. L. Order Cingulata. In: Wilson, D. E. \& Reeder, D. M. (Eds.). Mammal Species of the World. $3^{\text {rd }}$ ed. Baltimore, Johns Hopkins University Press, 2005. pp.94-9.

Gaudin, T. J. \& Wible, J. R. The phylogeny of living and extinct armadillos (Mammalia, Xenarthra, Cingulata): A craniodental analysis. In: Carrano, M. T.; Gaudin, T. J.; Blob, R. W. \& Wible, J. R. (Eds.). Amniote Paleobiology: Perspectives on the Evolution of Mammals, Birds, and Reptiles. Chicago, University Of Chicago Press, 2006. pp.153-98.

Gaudin, T. J.; Wible, J. R.; Hopson, J. A. \& Turnbull, W. D. Reexamination of the morphological evidence for the Cohort Epitheria (Mammalia, Eutheria). J. Mammal. Evol., 3(1):3179, 1996. 
Guth, C. La région temporale des Édentés. Doctoral dissertation, Paris, University of Paris, 1961. p.197.

Hemilä, S.; Nummela, S. \& Reuter, T. What middle ear parameters tell about impedance matching and high frequency hearing. Hear. Res., 85(1-2):31-44, 1995.

Heth, G.; Frankenberg, E. \& Nevo, E. Adaptive optimal sound for vocal communication in tunnels of a subterranean mammal (Spalax ehrenbergi). Experientia, 42(11-12):1287-9, 1986.

Khanna, S. M. \& Tonndorf, J. Middle ear power transfer. Arch. Klin. Exp. Ohren Nasen Kehlkopfheilkd., 193(1):78-88, 1969.

Lange, S.; Stalleicken, J. \& Burda, H. Functional morphology of the ear in fossorial rodents, Microtus arvalis and Arvicola terrestris. J. Morphol., 262(3):770-9, 2004.

Lavender, D.; Taraskin, S. N. \& Mason, M. J. Mass distribution and rotational inertia of "microtype" and "freely mobile" middle ear ossicles in rodents. Hear. Res., 282(1-2):97-107, 2011.

Mason, M. J. Middle ear structures in fossorial mammals: a comparison with non-fossorial species. J. Zool., Lond., 255(4):467-86, 2001.

Nevo, E. Adaptive convergence and divergence of subterranean mammals. Annu. Rev. Ecol. Syst., 10:269-308, 1979.

Nummela, S. Scaling of the mammalian middle ear. Hear. Res., 85(1-2):18-30, 1995.

Patterson, B.; Segall, W. \&Turnbull, W. D. The ear region in xenarthrans (= Edentata: Mammalia). Part I. Cingulates. Fieldiana: Geology (New Series), 18:1-46, 1989.

Patterson, B.; Segall, W.; Turnbull, W. D. \& Gaudin, T. J. The ear region in xenarthrans (= Edentata: Mammalia). Part II. Pilosa (sloths, anteaters), palaeanodonts, and a miscellany. Fieldiana: Geology (New Series), 24:1-79, 1992.

Plassmann, W. \& Brändle, K. A functional model of the auditory system in mammals and its evolutionary implications. In: Webster, D. B.; Fay, R. R. \& Popper, A. N. (Eds.). The Evolutionary Biology of Hearing. New York, Springer-Verlag, 1992. pp.637-53.

Schleich, C. E. \& Vassallo, A. I. Bullar volume in subterranean and surface-dwelling caviomorph rodents. J. Mammal., 84(1):185-9, 2003.

Segall, W. Further observations on the ear in fossorial mammals with special considerations of Chlamyphorus truncatus (Harlan). Acta Anat. (Basel), 94(3):431-44, 1976.

Squarcia, S. M.; Sidorkewicj, N. S. \& Casanave, E. B. The hypertrophy of the tympanic bulla in three species of dasypodids (Mammalia, Xenarthra) from Argentina. Int. J. Morphol., 25(3):597-602, 2007.

Webster, D. B. \& Plassmann, W. Parallel evolution of low-frequency sensitivity in old world and new world desert rodents. In: Webster, D. B.; Popper, A. N. \& Fay, R. R. (Eds.). The Evolutionary Biology of Hearing. New York, Springer-Verlag, 1992. pp.625-31.

Webster, D. B. \& Webster, M. The specialized auditory system of kangaroo rats. Contrib. Sens. Physiol., 8:161-96, 1984.

Wible, J. R. The Ontogeny and Phylogeny of the Mammalian Cranial Arterial Pattern. Ph.D. Dissertation, Durham, N. C., Duke University, 1984. p.705.

Wible, J. R. Petrosal anatomy of the nine-banded armadillo, Dasypus novemcinctus Linnaeus, 1758 (Mammalia, Xenarthra, Dasypodidae). Ann. Carnegie Mus., 79(1):1-28, 2010.

Wible, J. R. \& Gaudin, T. J. On the cranial osteology of the yellow armadillo Euphractus sexcinctus (Dasypodidae, Xenarthra, Placentalia). Ann. Carnegie Mus., 73(3):117-96, 2004.

\section{Dirección para Correspondencia: \\ Nora S. Sidorkewicj \\ Departamento de Biología, Bioquímica y Farmacia \\ Universidad Nacional del Sur \\ San Juan 670, 8000 Bahía Blanca \\ ARGENTINA}

Email: norasidorke@bvconline.com.ar

Recibido : 28-12-2011

Aceptado: 12-03-2012 